\title{
HUBUNGAN DUKUNGAN KELUARGA DENGAN KEPATUHAN PASIEN STROKE DALAM MELAKUKAN FISIOTERAPI DI RSUD H. SAHUDIN KUTACANE TAHUN 2021
}

\author{
Dina Andriani ${ }^{1}$, Desrina ${ }^{2}$ \\ ${ }^{1}$ STIKes Nurul Hasanah Kutacane \\ ${ }^{2}$ Akademi Keperawatan Teungku Fakinah Banda Aceh \\ Email:dinabrkaro@gmail.com,
}

\begin{abstract}
Family support is the help provided by the family to family members in need when facing problems whereas compliance is the extent to which the patient's behavior is in accordance with the provisions provided by the health professional. The design of this study is correlational. The goal is to find out the relationship of family support with the compliance of stroke patients in doing physiotherapy. Sampling using purposive sampling technique amounted to 22 respondents who were a family of stroke patients who did physiotherapy at RSUD Kutacane, Southeast Aceh Regency. The compliance rate of stroke patients in doing physiotherapy in the hospital is about $72.7 \%$ where families who provide support as much as 77.3\%. Based on the results of the analysis with fisher's exact test obtained the value $P$ (fisher $)=0.000$. Then there is a relationship between family support and the compliance of stroke patients in doing physiotherapy. These results show that if the family provides good support, then the patient's compliance with physiotherapy will be better as well. Based on the results of this study, the family should be able to provide support to patients. It is expected that the H. Sahudin of Southeast Aceh Regency Hospital, Educational Institutions and other related institutions will develop a permanent procedure on providing health education to patients and their families, especially about the importance of family support in the recovery of the patient's health.
\end{abstract}

\section{Keywords: Family support, stroke patient compliance, physiotherapy}

\section{PENDAHULUAN}

Seiring laju perkembangan peradaban dunia, banyak terjadi perubahan pola hidup dalam masyarakat. Masyarakat cenderung tidak disiplin dalam menerapkan pola makan gizi seimbang, gaya hidup yang tidak sehat sehingga akan memberikan dampak pada pergeseran pola penyakit, yaitu dari pola penyakit infeksius bergeser ke pola penyakit degeneratif. Salah satu penyakit degeneratif yang tampak menonjol adalah stroke (Andhyantoro, 2014).

\section{Data World Stroke Organization} menunjukkan bahwa setiap tahunnya 13,7 juta kasus baru stroke, dan sekita 5,5 juta kematian terjadi akibat penyakit ini. Sekitar $70 \%$ penyakit stoke dan $87 \%$ kematian dan disabilitas akibat stroke terjadi pada negara berpendapatan rendah dan menengah. Lebih dari empat decade tarkhir kejadian stroke pada negara berpendapatan rendah dan menengah meningkat lebih dari dua kali lipat. Selama 15 tahun terakhir, rata-rata 
stroke terjadi dan menyebabkan kematian kebih banyak pada negara berpendapatan rendah dan menengah dibandingkan dengan negara berpendapatan tinggi. (Kemenkes RI, 2019)

Penyakit stroke yang merupakan salah satu penyakit dengan biaya tertinggi, menghabiskan biaya pelayanan kesehatan sebesar 2,56 triliun rupiah pada tahun 2018 . Jumlah pasien stroke semakin meningkat setiap tahunnya, sehingga biaya pelayanan kesehatan semakin. Stroke menduduki urutan ketiga penyebab kematian setelah penyakit jantung dan kanker. Stroke masih merupakan penyebab utama dari kecacatan. Hal ini terlihat dari laporan survei Kesehatan Rumah Tangga Depkes RI di berbagai rumah sakit di 27 provinsi di Indonesia. Hasil survei itu menunjukkan terjadinya peningkatan antara 1984 sampai 2016, dari 0,72 per 100 penderita pada 2018 menjadi 0,89 per 100 penderita pada 2019 . Di RSUD Banyumas, pada 2017 pasien stroke yang rawat inap sebanyak 255 orang, pada 2018 sebnyak 298 orang, pada 2019 sebanyak 393 orang, dan pada 2020 sebanyak 459 orang (Kemenkes RI, 2019).

Stroke dapat dicegah dengan mengendalikan faktor resiko utamanya yaitu usia, tekanan darah tinggi, diabetes millitus dan beberapa jenis penyakit jantung serta hal - hal lain yang bisa berperan sebagai faktor resiko seperti kegemukan, kebiasaan merokok dan minum alkohol, kurang gerak dan stress (Gustiana, 2005 dalam Situmorang, 2015)). Menurut Rekam Medis RSUD H. Sahudin Kutacane, jumlah penderita stroke yang menjalani fisioterapi di ruangan fisioterapi pada tahun 2021 sebanyak 145 orang. Laki-laki sebanyak 74 orang $(51 \%)$ dan perempuan sebanyak 71 orang (49\%).

Keberhasilan fisioterapi sangat bergantung kepada dukungan keluarga. Semakin tinggi dukungan keluarga maka kepatuhan pasien akan semakin baik pula. Tanpa adanya dukungan keluarga fisioterapi tidak dapat dilakukan sesuai jadwal (Cahyadi, 2021). Dari uraian di atas peneliti tertarik untuk melakukan penelitian tentang "Hubungan Dukungan Keluarga dengan Kepatuhan Pasien Stroke dalam Melakukan Fisioterapi di Ruangan Fisioterapi RSUD H. Sahudin Kutacane".

\section{METODE}

Rancangan penelitian yang digunakan oleh peneliti adalah rancangan penelitian korelasional (Mustafa et al., 2020). Penlitian dilakukan RSUD H. Sahudin Kutacane. Populasi dalam penelitian ini adalah keluarga penderita stroke yang sedang menjalani fisioterapi sebanyak 145 orang. Sampel dalam penelitian ini sebanyak 22 orang dengan teknik sampling yaitu purposive sampling. Metode pengumpulan 
data dalam penelitian ini melalui data primer yaitu data dikumpulkan sendiri oleh peneliti melalui pemberian kuesioner pada responden, dan data sekunder yaitu data yang diperoleh dari RSUD H. Sahudin Kutacane. Setelah data diperoleh, kemudian dilakukan analisis untuk mencari ada tidaknya hubungan dukungan keluarga dengan kepatuhan pasien stroke dalam melakukan fisioterapi.

\section{HASIL DAN PEMBAHASAN}

\section{Hasil Penelitian}

Tabel 1. Distribusi frekuensi tingkat dukungan keluarga kepada pasien stroke di RSUD $H$. Sahudin Kutacane Tahun 2021.

\begin{tabular}{clcc}
\hline No & Dukungan Keluarga & $\mathbf{f}$ & $\mathbf{\%}$ \\
\hline 1 & Ada dukungan & 17 & 77,3 \\
2 & Tidak ada dukungan & 5 & 22,7 \\
\hline & Total & $\mathbf{2 2}$ & $\mathbf{1 0 0}$ \\
\hline
\end{tabular}

Bredasarkan Tabel 1 diatas dapat dilihat bahwa keluarga yang memberikan dukungan kepada pasien stroke dalam melakukan fisioterapi sebanyak 17 responden sebesar 77,3\%.

Tabel 2. Kategori respon kepatuhan pasien stroke dalam melakukan fisioterapi di RSUD H. Sahudin Kutacane Tahun 2021.

\begin{tabular}{llcc}
\hline No & Respon Kepatuhan & f & \% \\
\hline 1 & Patuh & 16 & 72,7 \\
2 & Tidak patuh & 6 & 27,3 \\
\hline & Total & $\mathbf{2 2}$ & $\mathbf{1 0 0}$ \\
\hline
\end{tabular}

Berdasarkan Tabel 2. dapat dilihat bahwa respon kepatuhan pasien dalam melakukan fisioterapi sebanyak 16 orang.

Tabel 3. Hubungan Antara Dukungan Keluarga Dengan Kepatuhan Pasien Stroke Dalam Melakukan Fisioterapi

\begin{tabular}{|c|c|c|c|c|c|c|c|}
\hline \multirow{3}{*}{$\frac{\text { Dukungan }}{\text { Keluarga }}$} & \multicolumn{4}{|c|}{ Respon Kepatuhan } & \multirow{2}{*}{\multicolumn{2}{|c|}{ Total }} & \\
\hline & \multicolumn{2}{|c|}{ Patuh } & \multicolumn{2}{|c|}{ Tidak Patuh } & & & \\
\hline & f & $\%$ & f & $\%$ & $\mathrm{f}$ & $\%$ & \multirow{3}{*}{0,000} \\
\hline Ada dukungan & 12 & 70,6 & 5 & 29,4 & 17 & 77,3 & \\
\hline$\frac{\text { Tidak ada }}{\text { dukungan }}$ & 4 & 80 & 1 & 20 & 5 & 22,7 & \\
\hline
\end{tabular}

Berdasarkan Tabel 3 diatas diperoleh hasil analisis Fisher's Exact Test dan diperoleh nilai $p$ (fisher) $=0,000$. Maka ada hubungan antara dukungan keluarga dengan kepatuhan pasien stroke dalam melakukan fisioterapi di Ruangan Fisioterapi RSUD H. Sahudin Kutacane tahun 2021.

\section{Pembahasan}

Setelah dilakukan penelitian didapatkan bahwa keluarga yang memberikan dukungan kepada pasien stroke dalam melakukan fisioterapi sebanyak 17 responden sebesar $77,3 \%$, dan yang tidak memberikan dukungan sebanyak 5 responden sebesar $22,7 \%$.

Dukungan pengharapan meliputi pertolongan pada individu untuk memahami kejadian depresi dengan baik dan juga sumber depresi dan strategi koping yang dapat digunakan dalam menghadapi 
stressor. Dukungan ini juga merupakan dukungan yang terjadi bila ada ekspresi penilaian yang positif terhadap individu.

Individu mempunyai seseorang yang dapat diajak bicara tentang masalah mereka, terjadi melalui ekspresi pengharapan positif individu kepada individu lain, penyemangat, persetujuan terhadap ide-ide atau perasaan seseorang dan perbandingan positif seseorang dengan orang lain, misalnya orang yang kurang mampu. Dukungan keluarga dapat membantu meningkatkan strategi koping individu dengan strategistrategi alternatif berdasarkan pengalaman yang berfokus pada aspek-aspek yang positif (Friedman, 2013). Berdasarkan hasil penelitian terdapat $29,6 \%$ dukungan dalam bentuk dukungan penghargaan dari keluarga. Dukungan yang bersifat penghargaan yang positif membuat individu merasa berarti, mampu dan merasa dirinya bernilai.

Dukungan nyata / fasilitas meliputi penyediaan dukungan jasmaniah seperti pelayanan, bantuan finansial dan material berupa bantuan nyata (instrumental support material support), suatu kondisi dimana benda atau jasa akan membantu memecahkan masalah praktis, termasuk di dalamnya bantuan langsung, seperti saat seseorang memberi atau meminjamkan uang, membantu pekerjaan sehari-hari, menyampaikan pesan, menyediakan transportasi, menjaga dan merawat saat sakit ataupun mengalami depresi yang dapat membantu memecahkan masalah (Friedman, 2013).

Berdasarkan hasil penelitian terdapat 24,6\% dukungan dalam bentuk dukungan nyata dari keluarga. Keterlibatan anggota keluarga secara terus-menerus merupakan hal yang sangat menolong dan membangkitkan semangat bagi penderita dalam menjalani pengobatan.

Dukungan informasi/ pengetahuan meliputi jaringan komunikasi dan tanggung jawab bersama, termasuk di dalamnya memberikan solusi dari masalah, memberikan nasehat, pengarahan, saran, atau umpan balik tentang apa yang dilakukan oleh seseorang. Keluarga dapat menyediakan informasi dengan menyarankan tentang dokter, terapi yang baik bagi dirinya, dan tindakan spesifik bagi individu untuk melawan stressor. Individu yang mengalami depresi dapat keluar dari masalahnya dan memecahkan masalahnya dengan dukungan dari keluarga dengan menyediakan feed back ((Friedman, 2013).

Berdasarkan hasil penelitian terdapat $23,7 \%$ dukungan dalam bentuk dukungan informasi dari keluarga. Pada dukungan informasi ini keluarga sebagai penghimpun informasi dan pemberi informasi. Keluarga merupakan sumber terbaik dalam penyediaan informasi dengan menyarankan 
tindakan yang spesifik dalam meningkatkan kepatuhan pasien dalam melakukan fisioterapi. Dengan adanya dukungan tersebut pasien mampu belajar dari pengalaman yang diceritakan orang lain.

Dukungan emosional merupakan dukungan yang membuat individu memiliki perasaan nyaman, yakin, diperlukan, dan dicintai oleh sumber dukungan keluarga (Friedman, 2013). Berdasarkan hasil penelitian terdapat $22,1 \%$ dukungan dalam bentuk dukungan emosional dari keluarga. Dukungan emosional dan perhatian dalam situasi kritis atau dalam keadaan sakit merupakan bagian yang sangat penting dalam pemeliharaan kesehatan. Pasien yang mendapat dukungan seperti ini akan merasa diperhatikan dan dilindungi.

Menurut peneliti dukungan keluarga di Ruangan Fisioterapi RSUD H. Sahudin Kutacane mayoritas penderita stroke memperoleh dukungan, akan tetapi masih ada keluarga yang tidak mampu sepenuhnya menemani pasien secara langsung. Peneliti melihat ada keluarga yang meninggalkan pasien saat fisioterapi dan yang berperan dalam memberikan semangat mayoritas adalah anak. Peran keluarga berkurang karena pekerjaan yang menuntut harus meninggalkan pasien. Hanya saja dukungan nyata selalu diperoleh pasien dari keluarga mereka.
Berdasarkan hasil yang diperoleh tingkat kepatuhan pasien stroke dalam melakukan fisioterapi di Ruangan Fisioterapi RSUD H. Sahudin Kutacane tahun 2021 bahwa respon kepatuhan pasien dalam melakukan fisioterapi sebanyak 16 orang sebesar $72,7 \%$ dan pasien yang tidak patuh sebanyak 6 orang sebesar 27,3\%.

Kepatuhan berasal dari kata dasar patuh, yang berarti disiplin dan taat. Menurut (Friedman, 2013), mendefinisikan kepatuhan pasien sebagai sejauh mana perilaku pasien sesuai dengan ketentuan yang diberikan oleh profesional kesehatan. Penyebab ketidakpatuhan pasien meliputi pemahaman tentang instruksi, kualitas interaksi, isolasi sosial dan keluarga, keyakinan, sikap dan kepribadian.

Berdasarkan hasil penelitian yang dilakukan bahwa dari 5 orang $(22,7 \%)$ pasien yang tidak patuh melakukan fisioterapi karena tidak ada dukungan dari keluarga sebaliknya dari 17 orang $(77,3 \%)$ pasien patuh melakukan fisioterapi karena memperoleh dukungan dari keluarga. Berdasarkan hasil analisis diperoleh nilai $p$ (fisher $)<0.05(\mathrm{p}=0,000)$ berarti Ho ditolak, maka ada hubungan yang bermakna secara statistik, antara dukungan keluarga dengan kepatuhan pasien stroke dalam melakukan fisioterapi di Ruangan Fisioterapi RSUD H. Sahudin Kutacane tahun 2021. 
Dukungan keluarga terhadap pasien menyebabkan adanya ketenangan dan rasa aman pada pasien. Hasil penelitian ini sesuai dengan penelitian yang dilakukan (Hendayani \& Sari, 2019) yang menyatakan bahwa pasien yang mendapatkan dukungan yang tinggi tidak menunjukkan kecemasan dan keluar lebih cepat dari rumah sakit dibandingkan pasien yang tidak diberi dukungannya. Saat pasien yakin bahwa mereka mempunyai keluarga yang mendukung maka kecemasan pasien akan berkurang..

Menurut peneliti keberhasilan fisioterapi sangat bergantung kepada dukungan yang diberikan oleh keluarga. Apabila keluarga memberikan dukungan yang baik, maka kepatuhan pasien akan semakin baik pula. Dengan dukungan keluarga maka akan meningkatkan motivasi pasien untuk melakukan fisioterapi sehingga akan meningkatkan kepatuhan.

\section{KESIMPULAN DAN SARAN}

\section{Kesimpulan}

Dari hasil penelitian tersebut dapat disimpulkan bahwa ada hubungan antara dukungan keluarga dengan tingkat kepatuhan pasien stroke dalam melakukan fisioterapi

\section{Saran}

Bagi Keluarga diharapkan dapat meningkatkan pengetahuan dalam memberikan dukungan terhadap pasien stroke yang melakukan fisioterapi secara optimal.

\section{DAFTAR PUSTAKA}

Andhyantoro. (2014). Kenali Stroke Secara Dini. http://www.imfokesehatan.com Cahyadi, D. (2021). Pengaruh Relaksasi Benson Terhadap Tingkat Depresi Pasien Post Stroke DI RSUD Ungaran - Repository Universitas Ngudi Waluyo. http://repository2.unw.ac.id/1100/

Friedman. (2013). Keperawatan Keluarga. Teori dan Praktek Edisi Ketiga. EGC. Hendayani, W. L., \& Sari, D. M. (2019). Pengaruh Dukungan Keluarga Terhadap Konsep Diri Pasien Stroke Yang Mengalami Kelumpuhan Di Poli Klinik Saraf Rumah Sakit Stroke Nasional Bukittinggi Tahun 2018. Jurnal Kesehatan Medika Saintika, $10(1)$

Kemenkes RI. (2019). Stroke Dont Be The One (p. 10).

Mustafa, P. S., Gusdiyanto, H., Victoria, A., Masgumelar, N. K., Nurika Dyah Lestariningsih, Maslacha, H., Ardiyanto, D., Hutama, H. A., Boru, M. J., Iwan Fachrozi, E. I. S. R., Prasetyo, T. B., \& Romadhana, S. (2020). Metodologi Penelitian Kuantitatif, Kualitatif, dan Penelitian 
Tindakan Kelas dalam Pendidikan

Olahraga. Fakultas Ilmu

Keolahragaan Universitas Negeri

Malang.

Situmorang, T. (2015). Hubungan

Dukungan Keluarga Dengan Upaya

Keluarga Terhadap Pencegahan

Timbulnya Kekambuhan Stroke Di Upt

Pelayanan Sosial Anak Balita Dan

Lanjut Usia Wilayah Binjai Medan |

\begin{tabular}{l|l} 
Situmorang & JURNAL
\end{tabular}

KEPERAWATAN

FLORA.

https://ojs.stikesflora-

medan.ac.id/index.php/jkpf/article/vie

w/54 